\title{
Gender does not affect the prognosis of Fournier's gangrene: a case-matched study
}

\author{
Pınar Sarkut, M.D., ${ }^{1}$ Özgen Işık, M.D.,, Ersin Öztürk, M.D.,, ${ }^{1}$ Barış Gülcü, M.D.,, \\ İlker Ercan, M.D., ${ }^{2}$ Tuncay Yılmazlar, M.D. ${ }^{1}$
}

${ }^{1}$ Department of General Surgery, Uludağ University Faculty of Medicine, Bursa-Turkey

${ }^{2}$ Department of Biostatistics, Uludağ University Faculty of Medicine, Bursa-Turkey

\begin{abstract}
BACKGROUND: Female gender is accepted as a poor prognostic factor for Fournier's gangrene (FG). However, there is a paucity of data in the literature regarding this matter. This case-matched study was designed to investigate the impact of gender on outcomes of FG.

METHODS: Study patient data were retrieved from 120-patient, prospectively maintained database. Thirty-two female patients with FG were case-matched to 32 male patients based on symptom duration (days), FG severity index score, patient age, etiology, and presence of diabetes mellitus (DM) terms. Outcomes of FG were compared between the 2 groups.

RESULTS: Median age was 57 years (range: 22-80 years), and 35 (54.7\%) patients had DM. Patients underwent average of 3 debridement procedures (range: I-9 debridements), and I5 (23.4\%) received diverting stoma. Overall mortality rate was $28.1 \%$ (I8 of 64 patients). Female gender was associated with widespread disease $(p=0.009)$, increased need for consecutive debridements $(p=0.005)$, prolonged length of intensive care unit stay $(p=0.035)$, and increased requirement for split-thickness skin graft reconstruction $(p=0.040)$. However, mortality rates were comparable between genders $(p=0.264)$.
\end{abstract}

CONCLUSION: FG is often more extensive in females and seems to be associated with anatomical features of female pelvis. However, female gender is not a factor affecting prognosis of patients with FG.

Keywords: Fournier's gangrene; gender; mortality.

\section{INTRODUCTION}

Fournier's gangrene (FG) was first described in males. It is now known to be a potentially fatal soft tissue infection that affects males, females, and even children. ${ }^{[1]}$ Although the disease is more common among males, it has been reported that mortality due to FG is higher for females. ${ }^{[2-4]}$ This discrepancy may be associated with anatomical differences between genders.

FG may not be common among females because the perineal region can drain easily via the vagina. This anatomical feature

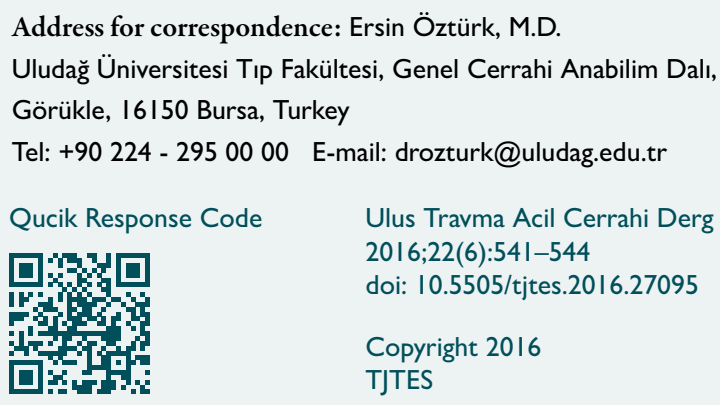

appears to be an advantage, but there is a direct connection between the female genitalia and the intra-abdominal space through the fallopian tubes. Anatomy of the female pelvis may also lead to rapid progression of FG and is considered to be linked to fatal peritonitis, which is associated with increased mortality. ${ }^{[2]}$ Previously published studies have reported that female gender is a poor prognostic factor for FG and suggested that gender does not affect prognosis. ${ }^{[4]}$ However, there are no published data available focusing directly on impact of gender on outcomes of FG.

In this study, we aimed to investigate whether female gender affects prognosis of FG by analyzing case-matched data derived from large, single-center database.

\section{MATERIALS AND METHODS}

After obtaining institutional review board approval, data for this study were extracted from prospectively maintained departmental FG database of 120 patients who were treated in our department between 1996 and 2012. Female patients were matched to male counterparts based on the following 
criteria that are well-known factors associated with outcomes of FG: symptom duration (days), FG severity index score, patient age, etiology, and presence of diabetes (DM). In total, 32 female patients matched to 32 males were included in the study. The 2 groups were compared based on grade of disease-spread, number of debridement procedures, number of stomas required, and mortality rate.

All patients underwent at least I radical debridement of the affected devitalized tissue within 12 hours of admission. Intravenous third-generation cephalosporin and metronidazole antibiotherapy was initiated in the emergency room and continued. Empiric antibiotherapy was changed as required according to microbiological analysis results of removed tissue samples in first debridement. During wound exploration at the time of wound dressing change, patients underwent additional debridement procedures as necessary. Additional debridements were performed until all necrotic tissue was removed and healthy granulation tissue was established in the wound. Patients with severe sepsis and patients requiring vasopressors or mechanical ventilation support were treated in the intensive care unit (ICU). Skin defects that were not appropriate for staged tertiary closure were reconstructed with split-thickness skin graft (STSG).

A previously published ${ }^{[5]}$ 3-grade scoring system was used to assess degree of spread. ${ }^{[5]}$ Grade I was identified as FG involving the perineum, scrotum and penis, vulva, or perianal region. In addition to meeting the criteria for grade I, grade II spread of FG was localized in the pubic region or femoralpelvic region, while in grade III it extended beyond the pelvic region.

Categorical variables were reported as frequency (\%) and quantitative variables were reported as the mean \pm standard deviation, except when noted otherwise. Categorical variables were compared using Fisher exact or chi-square test, and quantitative and ordinal variables were compared using Mann-Whitney $U$ or Wilcoxon rank sum test. $P$ value of $<0.05$ was considered statistically significant. All statistical analyses were performed using JMP software, version 10.0 (SAS Institute Inc., Cary, NC, USA).

\section{RESULTS}

There were 64 patients in the study with median age of 57 years (range: $22-80$ years). Etiology of FG was anorectal in $51.5 \%$ of the patients, while other cases of FG originated urogenitally. There were 35 patients with DM, and median duration of symptoms was 7 days (range: 3-35 days). Patients underwent an average of 3 debridement procedures (range: I-9 debridements). Median length of ICU stay and hospital stay were 0 days (range: $0-40$ days) and 7 days (range: 3-65 days), respectively. Diverting stoma was necessary for $23.43 \%$ of the patients. STSG was required for $40.62 \%$ of wound closures. Overall mortality rate was $28.12 \%$.

Results of comparison of the 2 groups based on matching criteria are provided in Table I. Majority of male patients (62.50\%) had grade I disease-spread, while FG was limited to the perineum, vulva, or perianal region in only $25.0 \%$ of females. Time from onset of symptoms to first debridement was comparable between genders; however, grade II and grade III FG was significantly more common in females. Frequency of grade III disease in females was more than double that in males: $31.25 \%$ of all patients had Grade III spread, and $70 \%$ of those were female $(p=0.009)$. Distribution of patients based on grade of disease-spread can be seen in Table 2 .

Female gender was associated with increased debridement count, prolonged length of ICU stay, and increased need for wound reconstruction with STSG. However, need for mechanical ventilation support, length of hospital stay, need for diverting stoma, and mortality rates (34.38\% vs $21.88 \%$; $\mathrm{p}=0.266$ ) were comparable in the 2 groups (Table 3 ).

\section{DISCUSSION}

Although FG affects both genders regardless of age, it occurs less frequently among women compared with men. Female/ male ratio varies between $\mathrm{I} / \mathrm{I} 0$ and $\mathrm{I} / 50 .{ }^{[8,9]}$ In spite of emerg-

Table I. Comparison of the 2 groups based on matching criteria ${ }^{\pi}$

\begin{tabular}{lccc}
\hline & Female $(\mathbf{n}=32)$ & Male $(\mathbf{n}=32)$ & p \\
\hline Age & $56(22-65)$ & $57(32-80)$ & 0.48 \\
Etiology & & & 0.21 \\
$\quad$ Anorectal & $43.8 \%$ & $59.4 \%$ & \\
$\quad$ Urogenital & $56.2 \%$ & $40.6 \%$ & \\
Diabetes mellitus & $65.6 \%$ & $43.8 \%$ & 0.07 \\
Symptom duration (days) & $8(3-30)$ & $7(3-35)$ & 0.82 \\
FGSI score & $6(5-8)$ & $6(5-7)$ & 0.89
\end{tabular}

"Categorical variables were reported as frequency (\%) and quantitative variables were reported as median (range). FGSI: Fournier's Gangrene Severity Index. 
Table 2. Distribution of the patients based on disease-spread grade

\begin{tabular}{lccc}
\hline & Female (\%) & Male (\%) & p \\
\hline Grade I & 25 & 62.5 & $0.009^{*}$ \\
Grade II & 31.3 & 18.8 & \\
Grade III & 43.8 & 18.8 & \\
\hline *: Chi-square test. & & &
\end{tabular}

ing technologies and advances in medical knowledge, it is still a fatal disease. Thus, mortality is still the major outcome parameter for FG. After analysis of case-matched data, our results revealed that FG is more aggressive in females; however, patient gender did not seem to influence mortality.

The infection that triggers the mechanism of necrotizing soft tissue infection arises from the perianal or urogenital region and rapidly spreads to the fascial planes. The most important fascia associated with the extension of the disease is Colles' fascia, which continues superiorly as Scarpa's fascia. ${ }^{[10]}$ Colles' fascia is inferiorly attached to the ischiopubic rami and posteriorly attached to the urogenital diaphragm in females. However, it is not anteriorly attached, which may cause early extension of infection to the anterior abdominal wall in females. ${ }^{\left[{ }^{11}\right]}$ In the present study, female patients had more extensive disease compared to males, and they underwent debridements more frequently than males. Although symptom duration was comparable between the 2 groups, majority of the males had grade I disease $(62.50 \%$ vs $25.0 \%)$, while grade III disease was more frequent among females $(43.75 \%$ vs $18.75 \%$ ). Greater number of debridements in female patients may be associated with need for recurrent removal of devitalized tissue in order to control widespread necrotizing fasciitis. Prolonged ICU length of stay for females may be explained by need for excessive care to treat sepsis associ- ated with extensive FG. Moreover, length of hospital stay was comparable between groups.

Creation of diverting stoma is preferred by some authors in order to facilitate wound care in FG patients, ${ }^{[9,12,13]}$ while other authors claim that stomas provide no benefits. ${ }^{[9,14]}$ Additionally, it has been reported that stoma creation is associated with high risk of mortality in FG patients. ${ }^{[15,16]}$ However, creating stoma is sometimes unavoidable in order to control fecal contamination of open wound. Interestingly, frequency of diverting stoma was comparable between genders in our study, despite the finding that the disease was more widespread in females.

Staged wound closure by tertiary intent can be performed for skin defects occurring after debridements for FG. However, reconstructive procedures may be necessary in some patients. ${ }^{[17-19]}$ Our data showed that need for reconstruction was higher among female patients. Higher chance of staged tertiary closure for male patients may be associated with healthy scrotal skin that may facilitate wound closure by providing extra skin, especially in patients without urogenital etiology.

FG is a fatal disease with mortality rate ranging from $3 \%$ to $40 \% .^{\left[{ }^{1]}\right.}$ There are several studies reporting an increased mortality rate for female gender, ${ }^{[2-5]}$ and female gender has even been reported as a risk factor for mortality in FG patients. ${ }^{[2]}$ In a previously published study, we reported a mortality rate of $30.8 \%$ for female patients, while it was $16 \%$ for males in our recently published study; however, we failed to show gender as a risk factor of mortality $(p=0.454) .{ }^{[4]}$ Similarly, analysis of case-matched data did not show statistically significant difference in mortality rates by gender, though mortality rate for females was higher than for males $(34.38 \%$ vs $21.88 \%$; $p=0.266$ ). This finding suggests that female gender may be an advantage to survival despite the involvement of larger areas of soft tissue.

Table 3. Comparison of outcomes of Fournier's gangrene by gender"

\begin{tabular}{lccr}
\hline & Female $(\mathbf{n = 3 2})$ & Male $(\mathbf{n = 3 2})$ & $\mathbf{p}$ \\
\hline Debridement count & $3.5 \pm 1.8$ & $2 . \pm 2.1$ & $0.005^{*}$ \\
Length of intensive care unit stay (days) & $6.2 \pm 9.3$ & $2.8 \pm 5.4$ & $0.035^{*}$ \\
Mechanical ventilation support (days) & $3.3 \pm 6.4$ & $1.2 \pm 2.8$ & 0.14 \\
Length of hospital stay (days) & $18.5 \pm 12.8$ & $14.7 \pm 13.1$ & 0.07 \\
Diverting stoma & $15.6 \%$ & $31.3 \%$ & 0.14 \\
Wound closure & & & $0.04^{\#}$ \\
Tertiary & $46.9 \%$ & $71.9 \%$ & $28.1 \%$ \\
Split thickness skin graft & $53.1 \%$ & $21.9 \%$ & 0.26 \\
Mortality & $34.4 \%$ & & \\
\hline "Categorical variables were reported as frequency (percentage) and quantitative variables were reported as mean \pm standard deviation.. \\
"Wilcoxon rank sum test. "Chi-square test.
\end{tabular}


Main limitation of this study is its retrospective nature. Although we have one of the largest single-center databases for FG, limited number of patients may also limit strength of this research. Further, studying case-matched data based on strict matching criteria gives this paper clinical value. To the best of our knowledge, this is the first case-matched study comparing outcomes of FG by gender.

In conclusion, FG is more widespread in females when compared with males, and female patients require additional debridements to manage the disease, possibly proportional to the amount of affected body surface area. Performing frequent debridements and occurrence of severe sepsis due to extensive disease may account for the prolonged length of ICU stay in females. Another result of widespread disease that may be unavoidable is greater need for STSG in closing female patients' wounds. However, gender does not seem to be a prognostic factor affecting mortality rate of patients with FG.

\section{Conflict of interest: None declared.}

\section{REFERENCES}

1. Eke N. Fournier's gangrene: a review of 1726 cases. Br J Surg 2000;87(6):718-28. Crossref

2. Czymek R, Frank P, Limmer S, Schmidt A, Jungbluth T, Roblick U, et al. Fournier's gangrene: is the female gender a risk factor? Langenbecks Arch Surg 2010;395:173-80. Crossref

3. Taviloglu K, Cabioglu N, Cagatay A, Yanar H, Ertekin C, Baspinar I, et al. Idiopathic necrotizing fasciitis: risk factors and strategies for management. Am Surg 2005;71:315-20.

4. Yılmazlar T, Işık Ö, Öztürk E, Özer A, Gülcü B, Ercan İ. Fournier's gangrene: review of 120 patients and predictors of mortality. Ulus Travma Acil Cerrahi Derg 2014;20:333-7. Crossref

5. Yilmazlar T, Ozturk E, Ozguc H, Ercan I, Vuruskan H, Oktay B. Fournier's gangrene: an analysis of 80 patients and a novel scoring system. Tech
Coloproctol 2010;14:217-23. Crossref

6. Yanar H, Taviloglu K, Ertekin C, Guloglu R, Zorba U, Cabioglu N, et al. Fournier's gangrene: risk factors and strategies for management. World J Surg 2006;30:1750-4. Crossref

7. Ersoz F, Sari S, Arikan S, Altiok M, Bektas H, Adas G, et al. Factors affecting mortality in Fournier's gangrene: experience with fifty-two patients. Singapore Med J 2012;53(8):537-40.

8. Hasdemir AO, Büyükaşik O, Cöl C. The clinical characteristics of female patients with Fournier's gangrene. Int Urogynecol J Pelvic Floor Dysfunct 2009;20:1439-43. Crossref

9. Liang SG, Chen HH, Lin SF, Chang CL, Lu CC, Hu WH. Fournier's Gangrene in Female Patients. J Soc Colon Rectal Surgeon (Taiwan) 2008;19:57-62.

10. Morpurgo E, Galandiuk S. Fournier's gangrene. Surg Clin North Am 2002;82:1213-24. Crossref

11. Yavagal S, de Farias TF, Medina CA, Takacs P. Normal vulvovaginal, perineal, and pelvic anatomy with reconstructive considerations. Semin Plast Surg 2011;25:121-9. Crossref

12. Bronder CS, Cowey A, Hill J. Delayed stoma formation in Fournier's gangrene. Colorectal Dis 2004;6:518-20. Crossref

13. Ayan F, Sunamak O, Paksoy SM, Polat SS, As A, Sakoglu N, et al. Fournier's gangrene: a retrospective clinical study on forty-one patients. ANZ J Surg 2005;75:1055-8. Crossref

14. Ozturk E, Sonmez Y, Yilmazlar T. What are the indications for a stoma in Fournier's gangrene? Colorectal Dis 2011;13:1044-7. Crossref

15. Yaghan RJ, Al-Jaberi TM, Bani-Hani I. Fournier's gangrene: changing face of the disease. Dis Colon Rectum 2000;43:1300-8. Crossref

16. Benizri E, Fabiani P, Migliori G, Chevallier D, Peyrottes A, Raucoules M, et al. Gangrene of the perineum. Urology 1996;47:935-9. Crossref

17. Korkut M, Içöz G, Dayangaç M, Akgün E, Yeniay L, Erdoğan O, et al. Outcome analysis in patients with Fournier's gangrene: report of 45 cases. Dis Colon Rectum 2003;46(5):649-52. Crossref

18. Chen SY, Fu JP, Wang CH, Lee TP, Chen SG. Fournier gangrene: a review of 41 patients and strategies for reconstruction. Ann Plast Surg 2010;64:765-9. Crossref

19. Chen SY, Fu JP, Chen TM, Chen SG. Reconstruction of scrotal and perineal defects in Fournier's gangrene. J Plast Reconstr Aesthet Surg 2011;64:528-34. Crossref

\title{
ORIJIINAL ÇALIŞMA - ÖZET
}

\section{Cinsiyet Fournier gangreni prognozuna etkili bir faktör değildir: Olgu-eşleme çalışması Dr. Pınar Sarkut,, ${ }^{1}$ Dr. Özgen Işık, ${ }^{1}$ Dr. Ersin Öztürk, ${ }^{1}$ Dr. Barış Gülcü,, ${ }^{1}$ Dr. İlker Ercan, ${ }^{2}$ Dr. Tuncay Yılmazlar ${ }^{1}$}

\begin{abstract}
${ }^{1}$ Uludağ Üniversitesi Tıp Fakültesi, Genel Cerrahi Anabilim Dalı, Bursa
Uludağ Üniversitesi Tıp Fakültesi, Biyoistatistik Anabilim Dalı, Bursa

AMAÇ: Kadın cinsiyet Fournier gangreni (FG) için olumsuz bir prognostik faktör olarak görülmektedir. Ancak literatürde bu konuya özgün yeterli veri yoktur. Bu olgu-eşleme çalışması kadın cinsiyetin FG prognozuna etkisini incelemek için yapıldı.

GEREÇ VE YÖNTEM: Çalışmaya alınan hastalar kliniğimizin 120 hastalık ileriye yönelik olarak tutulan veritabanından çekildi. Otuz iki kadın hasta aşağıdaki kriterler baz alınarak 32 erkek hastayla eşleştirildi: Semptom süresi, FG severity indeks (FGSI) skoru, hasta yaşı, etiyoloji ve eşlik eden diyabetes mellitus (DM) varlığı. Daha sonra iki grup hasta klinik sonuçlar açsından karşılaştırıldı.

BULGULAR: Medyan yaş 57 (22-80) idi ve 35 (\%54.7) hastada DM vardı. Hastalara ortalama 3 (I-9) debridman yapıldı ve I5 hastaya (\%23.4) saptıııı stoma açıldı. Mortalite oranı \%28.I (64'te 18 hasta) idi. Kadınlarda FG daha yaygındı ( $p=0.009)$, daha fazla debridmana ihtiyaç duyulmuştu $(p=0.005)$, kadınlar yoğun bakım ünitesinde daha fazla oranda kalmışı $(p=0.035)$ ve kadınlarda split thickness skin graft (STSG) ile rekonstrüksiyon daha fazla oranda yapılmışı $(p=0.040)$, ancak mortalite oranları iki grup arasında benzerdi $(p=0.264)$.

TARTIŞMA: Fournier gangreni kadınlarda erkeklere oranla daha yaygın seyreder. Bu muhtemelen kadınların anatomik yapısı ile ilgilidir. Ancak kadın cinsiyet FG mortalitesini artıran bir faktör değildir.

Anahtar sözcükler: Cinsiyet; Fournier gangreni; mortalite.
\end{abstract}

